\author{
ADAM ŁUKASZEWICZ \\ Uniwersytet Warszawski \\ e-mail: Adam.Lukaszewicz@adm.uw.edu.pl
}

\title{
REMARKS ON OVID AND THE GOLDEN AGE OF AUGUSTUS
}

\begin{abstract}
Adam, Remarks on Ovid and the Golden Age of Augustus (Uwagi o Owidiuszu $i$ złotym wieku Augusta).

Publius Ovidius Naso was an outstanding poet of the Augustan age who after a period of successful activity was suddenly sent to exile without a formal judicial procedure. Ovid wrote frivolous poems but inserted into his works also the obligatory praises of Augustus. The standard explanation of his relegation to Tomis is the licentious content of his Ars Amatoria, which were believed to offend the moral principles of Augustus. However, the Ars had been published several years before the exile. The poet himself in his Pontic writings mentions an unspecified error and a carmen, pointing also to the Ars, without, however, a clear explanation of the reason for his fall. The writer of the present contribution assumes that the actual reason for the relegation of the poet without a trial were the verses of his Metamorphoses and especially the passage about the wicked stepmothers preparing poison. That could offend Livia who, according to gossip, used poison to get rid of unwanted family members. Ovid was exiled, but the matter was too delicate for a public justification of the banishment. When writing ex Ponto the poet could not explicitly refer to the actual cause of his exile.
\end{abstract}

Keywords: Ovid; Augustus; golden age; exile; Metamorphoses; lurida aconita.

Ovid not only described the mythical golden age, he lived in the "golden age" of Augustus. The prophet of the golden age was Virgil. ${ }^{1}$ Anchises foretells the future glory of the empire: "Augustus Caesar, Divi genus, aurea condet / saecula qui rursus Latio regnata per arva / Saturno quondam." The words of Anchises in the Sixth Book of the Aeneid quoted above contain also a prophecy of future conquests of Augustus: "super et Garamantas et Indos / proferet imperium."

The Caspian lands and the Maeotid tremble of fear, Caesar is the terror of the mouths of the Nile. His conquests will overshadow the achievements of Hercules and the expedition of Bacchus, who returned from Nysa with his tigers. ${ }^{3}$ Apollo reappeared on earth in the person of his scion, whose divine origin was confirmed

\footnotetext{
${ }^{1}$ Levick 2010: 262.

${ }^{2}$ Verg. Aen. 6.791 sqq.

${ }^{3}$ Levick 2010: 266.
} 
by the story of Octavian's mother's, Atia's, dream. ${ }^{4}$ According to Asclepiades of Mendes, quoted by Suetonius, Atia conceived her son with Apollo. Before the delivery she had a dream in which her womb encompassed the whole universe. Atia's husband saw in a dream sunrays emerging from Atia's womb. ${ }^{5}$ This is a reflexion of Egyptian myths about the goddess $\mathrm{Nut}^{6}$ who gave birth to the sun and about the celestial goddess Hathor.

The son of Apollo would restore the golden age on earth. That idea is similar to the Egyptian concept of Maat, "truth," the universal order guaranteed by the king, ${ }^{8}$ who is an offspring of the queen and the sun-god Amun-Re. Augustus displayed his contempt for Egypt. ${ }^{9}$ However, some elements of his political ideology had a beginning in the Hellenized kingdom on the Nile. ${ }^{10}$ It is a question whether the adaptation of some Egyptian ideas to the requirements of the Roman propaganda was due to the Alexandrian renegade, the philosopher Areios, who accompanied the conqueror during his short sojourn in Egypt and whose advice was said to have contributed to the assassination of Ptolemy Caesarion, the true son of Julius Caesar. ${ }^{11}$ The conquest of Egypt found powerful expression in the princeps' propaganda concisely in his Achievements (Res gestae): "Aegyptum imperio populi [Ro] mani adieci" 12 and prophetically in Virgil, who "predicted" Augustus' control of the septemgemini... ostia Nili. ${ }^{13}$

The new province had paramount importance in the empire of Augustus. ${ }^{14}$ However, when Barbara Levick mentions Augustus' "predecessor on the throne of the pharaohs," ${ }^{15}$ which obviously refers to Cleopatra VII, her wording is not well chosen, since in actual fact Augustus did not sit on that throne. His status of a "pharaoh" sui generis found expression only within the Egyptian temple precincts, where the cult required the existence of a king. Otherwise, in Egypt Augustus was styled Kaisar or kópıı. ${ }^{16}$

\footnotetext{
${ }^{4}$ Suet. Aug. 94; Cassius Dio XLV 1.2-5; See Łukaszewicz 2006: 278-279; Łukaszewicz 2016: 487-499; Łukaszewicz 2017: 102.

${ }^{5}$ Suet. Aug. 94.4: "Somniavit et pater Octavius utero Atiae iubar solis exortum."

${ }^{6}$ Basic information can be found e.g. in Sauneron 1959a.

${ }^{7}$ For a brief entry on Hathor see e.g. Yoyotte 1959: 127; more information in Lexikon der Ägyptologie, s.v. "Hathor".

${ }^{8}$ For a brief definition of Maat see e.g. Sauneron 1959.

${ }^{9}$ For a concise overview of Octavian's conquest of Egypt see Łukaszewicz 2017. For Octavian's attitude towards Egypt see Łukaszewicz 2006: 225-235.

${ }^{10}$ Herklotz 2007; Łukaszewicz 2016: 495.

${ }^{11}$ Plut. Ant. 81.1; Łukaszewicz 2006: 187, 226.

${ }^{12}$ Augustus Res gestae 27.1.

${ }^{13}$ Verg. Aen. 6. 799.

${ }^{14}$ Licandro 2008.

${ }^{15}$ Levick 2010: 269.

${ }^{16} \mathrm{Cf}$. Bureth 1964.
} 
The cult of Augustus was modelled on Hellenistic patterns. The achievements of Alexander the Great and Julius Caesar were used as points of reference. It would be superfluous to insist on the tyrannous aspects of Alexander's rule. Also the definition of Julius Caesar as dittatore democratico is highly disputable. ${ }^{17}$ Not everybody must share the enthusiasm for the military expansion and destruction of the earlier political structures in the East. It was certainly a privilege of the epigone of Hellenism, the poet Konstantinos Kavafis, an Alexandrian man par

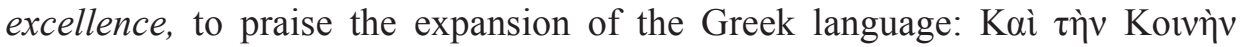

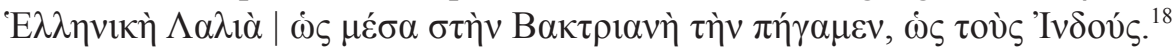

A prediction of Caius Octavius' rule over the world was due to the seer Publius Nigidius Figulus. The father of the child was so terrified that he was ready to kill the infant. The astrologer convinced him that he would not be able to do so. Octavian's divine status appears rather early in Virgil. ${ }^{19}$ Also, Ovid admired Augustus as a god, but he would praise him most eagerly in his Pontic writings, composed in the hope of winning the ruler's pardon.

Horace calls Augustus praesens divus, which is a purely Hellenistic vision of a god who is closer to people than the distant traditional deities. ${ }^{20}$ Barbara Levick translates this epithet as "immanent deity." ${ }^{21}$ However, Horace's words seem to mean a divinity present among the people and a living divus, a scion of the deceased divus Iulius.

During the 44 years of the informal monarchy, the adoration of the princeps was obligatory for men of letters. Propertius calls the new Caesar mundi servator. ${ }^{22}$ This epithet presented as an utterance of Apollo sounds like a religious confirmation of Augustus' rule over the world. The epithet of "saviour" was well known in Rome, although the pattern came from the Hellenistic world.

Suetonius reports after Iulius Marathus the prophecy of the birth of a "king to the Roman people" ("regem populo Romano naturam parturire"). ${ }^{23}$ The formula was not acceptable to the antimonarchic Roman society. The terrified senate was said to have decreed the extermination of all children to be born in that year. The husbands of pregnant women opposed and the decree was not promulgated. The similitude of that story to the essence of the tale of the massacre of the innocents by Herod is striking, especially that the story of the New Testament belongs to the reign of Augustus.

\footnotetext{
${ }^{17}$ Canfora 2006.

${ }^{18}$ Cavafis, Sta 200 p. Chr. (Cavafis 2013: 214).

${ }^{19}$ Verg. Ecl.1.

${ }^{20}$ Hor. Od. 3.5.1-4. Cf. the Athenian praise of the deified Demetrius Poliorcetes of 290 or 291

${ }^{21}$ Levick 2010: 267.

${ }^{22}$ Prop. Eleg. IV 6.36.

${ }^{23}$ Suet. Aug. 94.3.
} BC. 
The young Caesar was born when the Sun was in the sign of Libra. However, he considered Capricorn as his astrological symbol. ${ }^{24}$ It was not his ascendant or horoskopos. ${ }^{25}$ We know from Suetonius that Augustus was born on the 23th of September, $63 \mathrm{BC}$, shortly before the dawn, which points to $5.30 \mathrm{am}$. At that moment the ascendant was also the sign of Libra.

Was Capricorn the sign of Octavius' conception? Atia could be well aware of the moment. Capricorn agrees with the date of the proclamation of Octavian as Augustus. Was that day also the anniversary of his conception? If it were so, and if Octavius were conceived on the 16th of January, the gestation would be rather short. Suetonius states that the young Octavius was born ten months after his conception. ${ }^{26}$ It is a question whether this delay is to be taken precisely. If the conception took place 273 days before the date of birth (a time which was considered the usual duration of pregnancy) we have the date of the $23^{\text {rd }}$ of December, at the very beginning of Capricorn. Thus Octavius would have been conceived during the winter solstice and born during the autumnal aequinoctium. If, however, Suetonius' 10 months of the solar calendar are to be taken literally, the date of conception cannot be in Capricorn. Decisive, however, is the observation that among the extant ancient horoscopes all refer to the date of birth, not of conception. ${ }^{27}$ The choice of Capricorn as a symbol, if it is to be considered as a fact earlier than Octavian's proclamation as Augustus, remains enigmatic.

The horoscope of the future princeps by the astrologer Theogenes was published since, it was extremely promising. At first Octavian was reluctant to tell Theogenes his date of birth, since he feared that his horoscope would be less positive than the brilliant prediction for Agrippa whom magna et paene incredibilia praedicerentur..$^{28}$ Theogenes, however, fell to his customer's feet as a comment to his future fate.

There was an enormous discrepancy between the official propaganda praising the divine status and superhuman achievements of the ruler and the reality of life which generated the oppositional gossip. Octavius became a prospective successor of Julius Caesar in unclear circumstances which inspired gossip. There is no evidence of the falsification of Caesar's will, but a modification

\footnotetext{
${ }^{24}$ Jellonek 2017.

${ }^{25}$ Terio 2006.

${ }^{26}$ Suet. Aug. 94.4.

${ }^{27}$ Cf. Baccani 1992.

${ }^{28}$ Suet. Aug. 94.12.
} 
of that document after the Ides of March seems possible. The Egyptian queen Cleopatra VII and her son, the little Caesarion, were obliged to escape from Rome. ${ }^{29}$ Octavian became a specialist in handling documents: he seized and published the will of Mark Antony. Were the published contents genuine? His activities as pontifex maximus (since $12 \mathrm{BC}$ ) began with a purge of the Sibylline oracles which could have contained a matter of unwanted interpretations. ${ }^{30}$ At the end of his life he was afraid of unfavourable predictions and restricted the activities of astrologers. ${ }^{31}$

Octavian was not a talented military commander. The battle of Philippi was won by Mark Antony, while the young Caesar was hiding in the neighbouring bushes. ${ }^{32}$ The battle of Actium was won by Marcus Agrippa and Statilius Taurus. Egypt was conquered by Cornelius Gallus. Since 38 BC, Imperator was no longer a title (obtained in $43 \mathrm{BC}$ ) but the praenomen of Octavian (Imperator Caesar Divi filius). ${ }^{33}$ On the $16^{\text {th }}$ of January, $27 \mathrm{BC}$, Octavian was proclaimed Augustus. This strange epithet, which was little known in earlier times, must be connected with augurium. It was translated into Greek as $\Sigma \varepsilon \beta \alpha \sigma \tau o ́ s$. An alternative appellation of the princeps could have been "Romulus," but was rejected.

Suetonius describes the character of Octavian, including, next to his dissolute manners, his treacherous and cruel actions. The proscriptions of 43 $\mathrm{BC},{ }^{34}$ the cruelty after the battle of Philippi, ${ }^{35}$ the extermination of senators, equites and citizens of Perusia who supplicated for mercy, ${ }^{36}$ are persuasive evidence of Octavian's behaviour. He was pitiless to Cleopatra, whom he also possibly murdered, had her son, the natural heir to Caesar, executed, and caused the death of Mark Antony and Antony's eldest son. He had all Romans who were around Cleopatra and Mark Antony executed. ${ }^{37} \mathrm{He}$ did not spare his own helpers. Salvidienus Rufus, ${ }^{38}$ Cornelius Gallus, ${ }^{39}$ Marcus Egnatius, ${ }^{40}$ perhaps

\footnotetext{
${ }^{29}$ For the date: Cicero Ad Att. 14.8.1; see Łukaszewicz 2005: 200.

${ }^{30}$ Levick 2010: 192.

${ }^{31}$ Cassius Dio 56.25.5.

${ }^{32}$ Łukaszewicz 2005: 230.

${ }^{33}$ Augustus, Meine Taten/Res gestae, p. 82.

${ }^{34}$ Augustus, Meine Taten/Res gestae, p. 72.

${ }^{35}$ Augustus, Meine Taten/Res gestae, p. 76.

${ }^{36}$ Augustus, Meine Taten/Res gestae, p. 22-23, 77.

${ }^{37}$ Plut. Ant. 81.1-2; Cassius Dio LI 15.5; Oros. 6.19.

${ }^{38}$ Suet. Aug. 66.1 sq.; cf. Levick 2010: 36.

${ }^{39}$ Lukaszewicz 2015.

${ }^{40}$ Augustus, Meine Taten/Res gestae, p. 28.
} 
even Marcus Agrippa and others lost their lives since they were too talented and independent to survive. Cornelius Gallus, under the influence of wine, criticised the sovereign ${ }^{41}$ in the presence of some informants, among whom Valerius Largus has played the most disgusting role. The number of informers increased under Augustus, as Tacitus states. ${ }^{42}$

Writers were obliged to admire Augustus. Propertius calls the new Caesar mundi servator. ${ }^{43}$ This epithet in the mouth of Apollo sounds like a religious sanction to the lord of the world. The Hellenistic genesis of the idea of the ruler

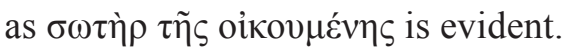

The degree of flattery in Augustan poetry varies from author to author. For example Tibullus does not mention Augustus at all in his (extant) works, while Virgil and Horace are very much engaged in praising the princeps. Maleuvre states even that Horace was "figé... dans le rôle de thuriféraire d'un regime profondément pervers." 44

An essential point was Augustus' divine status. ${ }^{45}$ This element is absent from the extant scraps of Gallus, where the flattery is limited to the perspective of Octavian's future prominent part in Roman history: "maxima Romanae pars eris historiae". ${ }^{46}$ At that time it was too early for praising the young Caesar as a god. The relationship between Gallus and Octavian was friendly, perhaps even comradely, and it would be odd if the poet called his boss a divinity. However, it seems that about $30 \mathrm{BC}$, the exceptional historical role was already a desirable element of the princeps' literary image.

Octavian's divine status appears rather early in Virgil. ${ }^{47}$ Also Ovid admired Augustus as a god, especially in his late writings. Tiberius will later speak of the divina mens of Augustus. ${ }^{48}$ Horace, Virgil, Propertius and Gallus, ${ }^{49}$ protégés of the ruler, ${ }^{50}$ were exceptionally talented. Velleius Paterculus extolls the benefactions of Augustus to the whole world, terrarum orbi, ${ }^{51}$ superior to the gifts of the gods. However, the benefits of Augustus to the writers were moderate when compared with his liberalitas to the family and political collaborators. ${ }^{52}$

The celebrations of the ludi saeculares of the 1st to 3rd of June, 17 BC, and the carmen saeculare by Horace set up the standard of political correctness

\footnotetext{
${ }^{41}$ Tristia II 444-445.

${ }^{42}$ Tac. Ann., 1.1.2. See Levick 2010: 276 (n. 111).

${ }^{43}$ Propertius, Eleg. IV 6.36.

${ }^{44}$ Maleuvre 1995: 53, quoted by Levick 2010: 271 (n. 89).

${ }^{45}$ Cf. Śnieżewski 1993.

${ }^{46}$ P. Qasr Ibrim Gallus col. I 3. Cf. Anderson, Parsons, Nisbet 1979.

${ }^{47}$ Verg. Ecl.1.

${ }^{48}$ For the speech of Tiberius to the Senate see Levick 2010: 298.

${ }^{49}$ Łukaszewicz 2015.

${ }^{50}$ For Gallus raised by Augustus ex infima fortuna: Suet. Aug. LXVI 2.

${ }^{51}$ Vell. Paterc. II 89.

${ }^{52}$ Łukaszewicz 1984.
} 
which included the glorification of Augustus. Ovid was less successful, although he also made a display of flattery in his Fasti. ${ }^{33}$ The golden age brought stability and peace in many regions, but also contained inritamenta malorum. A lot can be said about deficiencies of economy and about the dissent in Rome and in the provinces. ${ }^{54}$ Some republican idealists were induced to conspiracy which caused ruthless repression. The affairs in the ruling class generated gossip.

Augustus' autocracy reached a climax perhaps in $2 \mathrm{BC}$, when he was declared Pater Patriae. At the same time the mysterious scandal of Julia the Elder cast shadow on Augustus' family. ${ }^{55}$ Politics in Ovid are sometimes hidden between the verses of his mythological stories. A. Wallace-Hadrill states that Ovid - especially as author of the Fasti - was not an appropriate person to play a writer in the service of Augustus. ${ }^{56}$ This opinion is not entirely justified. Fasti do contain flattery, and even divine honours paid to Augustus, who shared his abode with Vesta and Apollo. ${ }^{57}$ The achievements of Augustus are duly praised in Ovid's work. The ultio of Augustus' "father" Julius Caesar found expression which could please the princeps. The vow to avenge Caesar is thus described in the Fasti:

\footnotetext{
"si mihi bellandi pater est Vestaeque sacerdos auctor, et ulcisci numen utrumque paro, Mars, ades et satia scelerato sanguine ferrum, statque favor causa pro meliore tuus.

templa feres et, me victore, vocaberis Ultor" voverat et fuso an hoste redit. (Fasti V 573-578)
}

In the course of time the whole series of civil wars was labelled as a righteous act of young Caesar's vengeance.

Metamorphoses are also full of attempts to bring the author into favour of the princeps, since by that time the cult of the ruler was obvious even to Ovid. At the end of the Metamorphoses we read a flattering description of Augustus' qualities and victories: Mutina, Philippi, Sicily and Egypt. ${ }^{58}$ Ovid joined the poets who, like Horace, heaped abuse on Cleopatra. Ovid did it in milder words than Horace, but he used the terms of the Augustan propaganda:

Romanique ducis coniunx Aegyptia taedae

Non bene fisa cadet; frustraque erit illa minata,

Servitura suo Capitolia nostra Canopo. (Met. XV 826-828)

\footnotetext{
${ }^{53}$ Mac Keown 1984: 187; cf. Levick 2010: 268 (n. 78).

${ }^{54}$ Levick 2010: 98-99.

${ }^{55}$ Levick 2010: 185.

${ }^{56}$ Levick 2010: 267 quotes this opinion. Wallace-Hadrill 1987: 228.

${ }^{57}$ Levick 2010: 154. Cf. Fasti 4.949-954.

${ }^{58}$ Met. XV 823-825.
} 
The apotheosis of Julius Caesar and praise of Augustus close the Metamorphoses. Many researchers, however, observed also in the Metamorphoses some evidence of Ovid's reserve and his reluctant attitude to join the choir of flatterers. ${ }^{59}$ According to Barbara Levick that view is "extreme. ${ }^{960}$ In actual fact we cannot consider Ovid a "neutral" or "dissident" poet of the Augustan age like Tibullus, who does not mention Augustus at all.

Ovid was exiled to Tomis on the Black Sea by Augustus in AD 8 without any legal procedure. Ovid makes a bitter comment on this way of sending him to the outskirts of the empire.

nec mea decreto damnasti facta senatus, nec mea selecto iudice iussa fuga est. tristibus invectus verbis - ita principe dignum ultus es offensas, ut decet, ipse tuas. (Tristia 2.131-134)

The mention of princeps'verba does not imply a meeting of Ovid with Augustus. Hutchinson interprets the verba as "an official and strongly-worded edictum." ${ }^{61}$ Even if the reason for the relegation was somehow explained to Ovid, it would not mean that he was informed about the true motive for Augustus' decision. An offence of Augustus was undoubtedly the cause of the poet's punishment. The matter was so much discussed in modern times, that it seems hardly possible to add a new comment to the enormous bibliography of Ovid's exile. ${ }^{62}$

The attention of innumerable commentators focuses on the frivolous and erotic writings of Ovid, incompatible with Augustus' policy. ${ }^{63}$ The main pieces of evidence in favour of the standard interpretation of poet's exile as a result of his erotic poetry are the statements by Ovid in his Pontic writings. Especially useful is a mention of his verses from the period of "imprudent youth" which became harmful in his old age:

Ergo quae iuvenis mihi non nocitura putavi

Scripta parum prudens, nunc nocuere seni. (Tristia II 543-544)

He says that his guilt is not new: "Supplicium patitur non nova culpa novum [...] Sera redundavit veteris vindicta libelli" (Tristia II 540, 545).

For that reason the Epitome de Caesaribus of c. AD 400, once attributed to Aurelius Victor, states that the reason for Ovid's exile was the Ars amatoria: "Nam

\footnotetext{
${ }^{59}$ Lundström 1980. Cf. Levick 2010: 268.

${ }^{60}$ Levick 2010: 268.

${ }^{61}$ Hutchinson 2017: 76.

${ }^{62}$ References to major publications on this large subject appear in footnotes below. For recent commentaries on the subject see Ingleheart 2011; Hutchinson 2017.

${ }^{63}$ Levick 2010: 267-271.
} 
poetam Ovidium, qui et Naso, pro eo quod tres libellos amatoriae artis conscripsit, exsilio damnavit." ${ }^{64}$ Why was he punished so late for the old Ars amatoria? Syme realised the problem and considered Ars amatoria as an excuse. ${ }^{65}$ In a recent study, G.O. Hutchinson who supports the view that the main reason for Ovid's exile was the Ars amatoria, explains that the delayed punishment was due to complex legal factors. Hutchinson also discusses the date of Ovid's exile which according to him could perhaps begin in AD 9 and not in $8 .{ }^{66}$

According to the statement of Suetonius, Augustus required that only excellent writers praise him and that they do it in a solemn literary context. Why should Augustus punish a correct flatterer only for inserting his flattery into a broad mythological context and for having in his younger years written frivolous verses? Was the style of the Fasti and of the Metamorphoses not serious enough to fit the princeps' taste?

Ovid declares also that he often wrote lies: "Magnaque parte mendax operum est et ficta meorum." ${ }^{67}$ Another reason for Ovid's exile often put forward in commentaries is the scandalous affair of the younger Julia. That idea is well summarised by the Vatican codex of Pomponius Laetus of the $15^{\text {th }}$ century: "Tandem cum venisset in suspicionem Augusti, creditus sub nomine Corinnae amasse Iuliam, in exsilium missus est. $" 68$

It is canonical to consider Ovid as a guilty party in the dissolute life of Julia, the granddaughter of Augustus, exiled in the same year as the poet. ${ }^{69}$ It seems strange, however, that both the daughter and the granddaughter of Augustus were accused of similar immoral conduct. The elder Julia was a mistress of Iullus Antonius, son of Mark Antony and Fulvia. Her adulterium and exile happened in the same AD 2 as the death of Lucius Caesar.

Jérôme Carcopino in his masterly work Passion et politique chez les Césars makes an impressive effort to demonstrate that Julia's portrait from Glanum shows an extremely proud and ambitious woman, greedy for political power. Interpretations of that kind are always very subjective. In the present author's eyes, Julia was a nice, round-faced representative of her social class. Her character is difficult to read from her sculpted visage. The statements of the authors about Julia's adulterium are biased commonplaces of the Augustan propaganda. Most researchers take these statements at face value.

The younger Julia, Augustus' granddaughter, was said to have committed adulterium with Decimus Junius Silanus. ${ }^{70}$ The involvement of Ovid in that

\footnotetext{
${ }^{64}$ Thibault 1964: 24.

${ }^{65}$ Syme 1978: 222; cf. Levick 2010: 268.

${ }^{66}$ Hutchinson 2017: 76, 80 (n. 64 and 65).

${ }^{67}$ Thibault 1964: 31.

${ }^{68}$ Thibault 1964: 27.

${ }^{69}$ Levick 2010: 188.

${ }^{70}$ Levick 1976.
} 
affair is entirely hypothetical and results from the chronological coincidence of his and Julia's exile. According to the poet's own statement, his crime was twofold, carmen and error: "Perdiderint cum me duo crimina, carmen et error" (Tristia II 207). Ovid is, however, reluctant to explain the nature of his error. He even expressed his desire to hide the sin:

Pars etiam quaedam mecum moriatur oportet,

Meque velim possit dissimulante tegi. (Tristia I 5.51-52)

Neve roges, quid sit, stultam conscripsimus artem. (Ex Ponto II 9. 73)

Ecquid praeterea peccarim, quaerere noli,

Ut lateat sola culpa sub Arte mea. (Ex Ponto II 9. 75-76)

Causa meae cunctis nimium quoque nota ruinae

Indicio non est testificanda meo. (Tristia IV 10.99-100)

That means: "I know, but I will not tell you. You should consider Ars amatoria as the reason of my fall." However, he mentions also some recent events: "si non extrema nocerent" and: "ultima me perdunt" (Tristia II 97-100). This is the opposite of the non nova culpa which caused a novum supplicium mentioned elsewhere. ${ }^{71}$ Is it a reference to the very fact of his exile or rather to a poem composed later than the Ars?

Some modern researchers considered Ovid's exile a literary fiction (see J.J. Hartmann, O. Janssen, A.D. Fitton Brown, H. Hofmann, Burkard Chwalek). ${ }^{72}$ That bold idea is not convincing and in this paper we take for granted an actual exile. It seems obvious that such an elaborate fiction is hardly thinkable in antiquity and would be aberrant.

On the other hand, there is no direct evidence of Ovid's exile, other than the poet's own writings from Tomis. Also Tacitus and Suetonius do not mention Ovid's misfortune. Only Pliny the Elder ${ }^{73}$ and Statius ${ }^{74}$ shortly mention the event. Later, we find the information in the Chronicle of Jerome of AD $381 .^{75}$

Some old and new authors assert that they know the reason for the exile, without any other basis than Ovid's own statements. ${ }^{76}$ The enormous bibliography of the question contains a variety of theories and explanations. ${ }^{77}$ They are listed

${ }^{71}$ Tristia II 540.

${ }^{72}$ Enumeration of earlier commentators who recommended the same view see Chwalek 1996, 29.

${ }^{73}$ Plin., Naturalis historia 32.152.

${ }^{74}$ Silv. 1.2 .254 sq.

${ }^{75}$ Cf. Gold 2004: 127; cf. Syme 1978: 215.

${ }^{76}$ E.g. Carcopino 1964: 132 sqq.; Thibault 1964; Chwalek 1996; for a review of modern interpretations: Ziolkowski 2005.

${ }^{77}$ E.g. Anonymous 1773. 
in Thibault's book of $1964 .^{78}$ Recently, Hutchinson suggested abandoning further speculation on the unknown error, since the actual problem was the Ars amatoria. $^{79}$

The fate of the poet can be also regarded through his own negative statements about the deeds which he did not commit. Ovid left an important statement concerning the reasons for the fall of Cornelius Gallus, a renowned poet and the first prefect of Egypt:

Non fuit opprobrio celebrasse Lycorida Gallo

sed linguam nimio non tenuisse mero. (Tristia II 444-445)

By the way, already in his earlier Amores Ovid said something remarkable about Gallus:

Tu quoque, si falsum est temerati crimen amici,

sanguinis atque animae prodige Galle tuae. (Am. III 9.63-64)

Ovid's statement is in disagreement with the official version about Gallus' offence of Augustus. The formula is polite to the princeps. Ovid says: "and you, Gallus, if it is not true that you offended your friend, why did you waste your blood and life?"

Tristia contain also another, less direct allusion to the fate of Gallus:

Non aliquid dixi ve, elatave lingua loquendo est,

Lapsaque sunt nimio verba profana mero. (Tristia III 5.47-48)

That means that he did not do what Gallus did. There are also other crimes he did not perpetrate:

Non ego caede nocens in Ponti litora veni

Mixtave sunt nostra dira venena manu

Nec mea subiecta convicta est gemma tabella

Mendacis linis imposuisse notam. (Ex Ponto II 9. 67-70)

Another motif concerns Ovid having inadvertently seen something dangerous.

Cur aliquid vidi? Cur noxia lumina feci?

Cur imprudenti cognita culpa mihi? (Tristia II 103-104)

Inscia quod crimen viderunt lumina plector

Peccatumque oculos est habuisse meum. (Tristia III 5.49)

\footnotetext{
${ }^{78}$ Thibault 1964: 125-129 (Appendix I).

${ }^{79}$ Hutchinson 2017: 76.
} 
Was having seen something Ovid's actual offence or only a regrettable little incident? ${ }^{80}$ One of the hypotheses is that Ovid saw Livia nude in bath. Tristia mention indeed the case of Actaeon: "Inscius Actaeon vidit sine veste Dianam...", ${ }^{11}$ which is also described in Metamorphoses.$^{82}$ In Rome, nudity could, however, be taken as lack of respect to the viewer, as we can assume from the story in Cassius Dio about some naked people who were seen by the indignant Livia. ${ }^{83}$ On the other hand, the dress was not a hindrance in sexual pleasures.

We can hardly imagine Ovid walking freely through the imperial appartments on the Palatine. Equally improbable is his seeing Augustus' incestuous intercourse with a woman or with a boy. Also the lines about Augustus playing Apollo can hardly be applied to the event under discussion ("Impia dum Phoebi Caesar mendacia ludit / Dum nova divorum cenat adulteria"). ${ }^{84}$ Even if Ovid indeed saw something emabrassing, was it the main reason of his relegation?

Ovid's exile happened immediately after the completion of the Metamorphoses. Even if not given a final touch, ${ }^{85}$ the work already circulated and was undoubtedly also read on the Palatine ${ }^{86}$ Is it the fact reflected in Tristia II 97-100 (supra, n. 81)?

Princeps, like many later rulers, read and censured the writers of the time. In the Metamorphoses he found a remarkable description of the mythical golden age. Toward the end that description grows more and more fantastic:

Ver erat aeternum, placidique tependibus auris

Mulcebant zephyri natos sine semine flores

Mox etiam fruges tellus inarata ferebat,

Nec renovatus ager gravidis canebat aristis;

Flumina iam lactis, iam flumina nectaris ibant. (Met. I 107-111)

The initial part concerning social life in the aurea aetas noticeably differs from the realities of the contemporaneous world. The mythical golden age is characterized as the opposite of the vicious present.

${ }^{80}$ Tristia II 103-105.

${ }^{81}$ Tristia II 105. Cf. Thibault 1964, 73.

${ }^{82}$ Met. III 138-252.

${ }^{83}$ Cassius Dio LVIII 2.

${ }^{84}$ Thibault 1964: 82-83 (n. 269). Cf. Garlow 1936: 103-105.

${ }^{85}$ Tristia III 14.23.

${ }^{86}$ Thibault (1964: 85, n. 286) states that the book was not published until Ovid's relegation (cf. Tristia I 7, 37; II 555; III 14. 22 sqq.) but agrees that it could be heard by Livia and Tiberius in private recitations. 
1) Without coercion (“...vindice nullo / Sponte sua sine lege” I 88-89) people behaved correctly ("fidem rectumque colebat" I 89).

2) There was no fear of punishment ("Poena metusque aberrant" I 91).

3) No dangerous regulations were published ("nec verba minantia fixo / Aere legebantur" I 91-92).

4) Common people were not terrorized by the authorities ("nec supplex turba timebat / iudicis ora sui" I 92-93). Iudex is not only a judge but any civil servant with judicial powers, which in Rome were not separated from administrative power.

5) Administrative and judicial structures were not necessary since people lived in security ("sed erant sine vindice tuti" I 93).

Even before the theories of the age of enlightenment concerning the contrat social, in Rome existed the idea of justification of the enforcement of law by the state as the price for the hope of security and of avoiding a bellum omnium contra omnes resulting from the vicious human nature.

6) There were no arms and no army ("Non galeae, non ensis erant: sine militis usu / Mollia securae peragebant otia gentes" I 99-100).

Later, in the bronze age, the tendency to use arms arose. ${ }^{87}$ This criticism of arma seems to be the opposite of Virgil's "Arma virumque cano."

The last period is the vicious iron age ("De duro est ultima ferro" I 127):

Omne nefas: fugere pudor verumque fidesque;

In quorum subiere locum fraudesque dolusque

Insidiaeque et vis et amor sceleratus habendi. (Met. I 129-131)

The relationships between neighbours, and in the family, are horrible:
Vivitur ex rapto: non hospes ab hospite tutus,
Non socer a genero; fratrum quoque gratia rara est.
Imminet exitio vir coniugis, illa mariti;
Lurida terribiles miscent aconita novercae;
Filius ante diem patrios inquirit in annos.
Victa iacet pietas, et Virgo caede madentes
Ultima caelestum terras Astraea reliquit. (Met. I 144-150)

This looks very much like an allusion to the poet's own time, perhaps except the conflict between a host and his guest, which may be an allusion to the death of Pompey who was seeking asylum in Egypt and was murdered by the tutors of the young king Ptolemy XIII. The present writer is convinced that the Egyptian government only fulfilled Julius Caesar's requirement and the responsibility was then shifted by Caesar on the treacherous clique of Ptolemy XIII. ${ }^{88}$

\footnotetext{
87 "Saevior ingeniis et ad horrida promptior arma" (I 126); "Non scelerata tamen" (I 127).

${ }^{88}$ The present writer's arguments for Caesar's responsibility for the assassination of Pompey were presented in Łukaszewicz 2016a: 36; Łukaszewicz 2007; Łukaszewicz 2018.
} 
What could Augustus think when reading the above words at the time when in Rome the ubiquitous gossip described in most horrible terms the situation in his family? What murderous couple was meant? Who is the dangerous son-inlaw? Is it Tiberius as ex-husband of Julia, Augustus' daughter? And the conflict of brothers? Who is the terrible stepmother who prepares poison? And who the son who would like to shorten his father's days, or who asks the astrologers about the length of his (adoptive) father's life?

The old tyrant would be naive if he did not see the malicious allusions. Did Ovid consider the insertion of such pungent examples into the description of the mythical vices of the iron age a sufficient camouflage? The Metamorphoses also contain the eulogies of Augustus, especially connected with the final apotheosis of Caesar.

Various aspects of the connexion of Juppiter with Augustus were considered the reason for the offence and punishment. ${ }^{89}$ Indeed the Iovis ira, mentioned in the final phrases of the Metamorphoses may be an allegory of repression by Augustus: $:^{90}$

Iamque opus exegi, quod nec Iovis ira nec ignes

nec poterit ferrum nec edax abolere vetustas. (Met. 15.871-872)

Ovid was not sentenced, since he could have been too eloquent in court. Also, the formula of accusation would be troublesome if it betrayed the actual reason of Augustus' anger. The poet learnt of the relegation when he was at the island of Elba. ${ }^{91}$ Perhaps Ovid destroyed his copy of the Metamorphoses when he learnt of the exile. Why was Ovid not cautious enough in his writings? Especially one line may be quoted as an evident allusion to the actual gossip: "Lurida terribiles miscent aconita novercae" ("Terrible stepmothers mix the lurid aconite," Met. I 147).

Aconitine is a very dangerous poison. A preparation of poison is what a stepmother would not typically do, in spite of some possible mythical prototypes. Such an image of a noverca agrees with the gossip about the premature death of the adopted sons of Augustus. ${ }^{92}$ Livia was generally suspected of poisoning and of intrigues to ensure the succession by her son Tiberius. Goodman states that long is the list of those whose death was ascribed to poison and intrigue of Livia. ${ }^{93}$ Ovid asserts that his exile is not punishment of poisoning. ${ }^{94}$

\footnotetext{
${ }^{89}$ Gold 2004.

${ }^{90}$ Gold 2004: 128 .

${ }^{91}$ Levick 2010: 188.

${ }^{92} \mathrm{On}$ the figure of stepmother in antiquity see Watson 1995.

${ }^{93}$ Goodman 1997: 43.

94 “Mixtave sunt nostra dira venena manu”, Ex Ponto II 9. 68.
} 
The idea of Georg Schoemann, coined in the $19^{\text {th }}$ century, that Ovid in the Metamorphoses offended Livia, who could not accuse him openly, since she would point to her own crimes, ${ }^{95}$ has been rejected. ${ }^{96}$ When I came to a similar conclusion some time ago, I did not know about a forgotten author of a short note who 137 years before detected the true reason for Ovid's exile. The universal rejection of the interpretation of Met. I 147-148 as a reference to the presumed deeds of Livia and Tiberius resulted from the observation that similar descriptions of a decline in the morals can allegedly be found in earlier authors. ${ }^{97}$ In actual fact the verses of Hesiod concerning the iron age (Erga 174-201) only very generally agree with the contents of Ovid's description of the wickedness of that period. The same can be said about the passage of Catullus (64.376-380). Ovid's allusion to specific relationships is much more direct and the reference to the family of Augustus seems obvious. Even if Ovid in his description of the horrors of the iron age was to a certain extent inspired by literary commonplaces, he, nevertheless, may have referred to the events of his own time. His use of known patterns for that purpose shows his mastery of the art of camouflage.

Schoemann thought that the delayed condemnation of the old frivolous poems was only necessary to cover the true reason of the poet's punishment which was to be forgotten.

However, an explicit accusation of Ovid as the author of the Ars amatoria probably did not take place at all. An official edictum containing a justification of the banishment of the poet is only a hypothesis. There was no trial, the exile was ordered in a "lettre de cachet" ante litteram. It was Ovid himself who suggested carmen et error.

The exile of Ovid took the mild form of relegation, apparently without loss of rights or confiscation of property. However, to a Roman gentleman of fashionable society, confinement to a remote place inhabited by barbarians and without comforts was a sufficient punishment for his "sins." Why so mild? Maybe Augustus did to a certain extent appreciate the fine verses of Ovid, especially the "frivolous" poems.

Thibault criticises the opinion of Horváth that Ovid saw Livia's preparations to poison Agrippa Postumus. ${ }^{98}$ In actual fact, no sources confirm that view. Thibault correctly says that Livia could buy the poison from specialists: "Nothing is more improbable than that Livia would be playing amateur pharmacist." ${ }^{\prime \prime 9}$ It is also true that Agrippa Postumus' death was not due to poison. He was executed by one of the guardians - undoubtedly at the order from Rome.

\footnotetext{
${ }^{95}$ Schoemann 1882: 171-175.

${ }^{96}$ Thibault 1964: 74, 85.

${ }^{97}$ Thibault (1964: 85) refers to Hesiod Erga 130-138, 181-201 and Catullus 64: 379 sqq.

${ }^{98}$ Horváth 1958: 385 sqq.

${ }^{99}$ Thibault 1964: 74.
} 
The gossip about Lucius and Gaius Caesars poisoned by Livia is reported by Tacitus. ${ }^{100}$ Of course "mixing aconita" must not be understood literally. And what about the son interested in the duration of his father's further life? In spite of ante diem which may simply refer to a moment of life when imminent death is not yet expected, inquirit must not suggest a direct intervention aiming at putting an end to the father's life, but rather a quest for illicit information. ${ }^{101}$ Tiberius, an amateur in astrology, could certainly consult the mathematici in matters of Augustus' life. Such inquiries concerning the ruler were forbidden. Augustus was superstitious. The bad omina were to be avoided or neutralised by sophisticated interpretations.

If Ovid's error was the passage from Metamorphoses, we would easily understand why neither Augustus (and Livia) nor Tiberius who ruled since AD 14 and certainly was still influenced by his witchy mother, pardoned Ovid. The idea that Tiberius was not ready to pardon Ovid because of the poet's contacts with the daughter of his former wife and that both were against the career of Tiberius, ${ }^{102}$ is as erroneous as the opinion that Tiberius, author of indecent verses and amateur of sophisticated luxury was outraged by licentious poems of Ovid. ${ }^{103}$

Suffice it to remind ourselves of the events in Augustus' family to understand the gossip of the period. It happened that Octavian's progeniture and his sonsin-law: Marcellus (23 BC) and Agrippa (12 BC) died prematurely. Also, his grandsons (and adoptive sons since $17 \mathrm{BC}$ ) died: Lucius (AD 2) and Gaius (AD 4). Both died abroad, but the vox populi accused Livia of having poisoned them by her agents. The daughter and the granddaughter of Augustus met their end in exile. Disfavour and persecutions touch Augustus' progeniture, not Livia's. An eloquent example is Agrippa Postumus. The son of Julia the Elder and thus the grandson of Augustus born in $12 \mathrm{BC}$ was adopted by the princeps together with Tiberius. At the age of 16 he had no honorific function yet, even not princeps iuventutis, and soon he fell into disgrace, was excluded from the gens Iulia and expulsed first to Surrentum, and then to a less pleasant island of Planasia 13 kilometres away from Elba. ${ }^{104}$ Immediately after Augustus' death, Postumus was executed. The official version said that it was Augustus' wish before death. The gossip, however, maintained that Augustus in his last months visited Planasia, reconciled with Postumus and wished to have him as successor. In the same tale both Augustus' death and Postumus' end were a consequence of the princeps' coup directed against Tiberius and Livia.

${ }^{100}$ Tac. Ann. I 3.

${ }^{101}$ Thibault (1964: 85) mentions a theory which interprets Met. I 147-148 as a reference to "Livia and Tiberius as murderers." In my opinion this formula contains an overinterpretation of I 148: "filius ante diem patrios inquirit in annos."

${ }^{102}$ Levick 2010: 270.

${ }^{103}$ On Tiberius' poems: Pliny the Younger, Ep. 5.3.5.

${ }^{104}$ Levick 2010: 187. 
The descendants of Livia and Tiberius Claudius Nero lived well. However, Drusus died in Germany in the late summer of 9 BC. He had an accident (fell from a horse) and was ill. His brother Tiberius from Ticinum reached Drusus before his death. The gossip interpreted Drusus' death as a result of Tiberius' hatred or poisoning by Augustus. Are the supposed earlier conflicts of the two brothers reflected in Ovid's verses? A lot was written to demonstrate that Tiberius was not guilty of Drusus' death. Drusus was loved by soldiers. His impressive funerary monument still stands at Mogontiacum (Mainz) on the Rhine. Even those who do not believe in the assassination of Drusus have to agree that the dramatic event of $9 \mathrm{BC}$ opened the career of Tiberius, who was raised to the position of Augustus' partner. ${ }^{105}$

There can be little doubt about Livia's intellectual qualities and her witchy character. ${ }^{106}$ A physiognomist could perhaps read that from her portraits. Her grandson Gaius (Caligula) called her "Ulixes stolatus" and said that she was guilty of the death of Marcellus (23 BC), Lucius and Gaius Caesars, Agrippa Postumus and Germanicus, and even Augustus. The conventional scholarship, however, remains sceptical. ${ }^{107}$

In the house of Augustus the struggle for succession continued. Ovidius knew that and could not abstain from making a comment, although his enunciation was less drastic than the words of the drunken Gallus, most probably concerning the transformation of Caesar into Augustus. Later the harsh conditions of the exile inspired his flattery, which was intended to cover up the "error." He even made a shameless remark that the Commonwealth is Caesar = Augustus (res est publica Caesar). ${ }^{108}$ Later this phrase was transformed into the arrogant saying of Louis XIV “L'État c'est moi.” Ovid addresses Caesar in his prayer: "Caesar, ades voto, maxime dive, meo!" ${ }^{109}$ His wish is:

di faciant igitur, quorum iustissimus ipse est,
alma nihil maius Caesare terra ferat,
utque diu sub eo, sic sit sub Caesare semper,
perque manus huius tradita gentis eat. (Ex Ponto I 2.97-100)

Why no revocation expressis verbis of his actual allusions, why a series of various misleading mentions? The reason is obvious. There was no formal accusation and no explicit explanation of the exile, only some written verba conveying Augustus' indignation. In theory Ovid could be unaware of the precise reason of his exile. That is exactly what he pretends to be. Ovid points

\footnotetext{
${ }^{105}$ Levick 2010: 98.

${ }^{106}$ Tac. Ann. 1.3; cf. Goodman 1997: 42.

${ }^{107}$ Oxford Classical Dictionary 1970: 614, s.v. "Livia Drusilla."

${ }^{108}$ Tristia 4.4.15.

${ }^{109}$ Tristia 3.1.78.
} 
to his Ars, mentions a mysterious error, and also suggests another explanation: "I saw something indecent." If he made his excuses for the real culpa, he would probably have to die. So he put forward some partly true explanations to mislead his persecutors and to prove that he was not aware of the real problem. He did not convince Augustus, Livia and Tiberius. He only succeeded in misleading future generations of readers.

\section{BIBLIOGRAPHY}

\section{Primary sources}

Augustus. Meine Taten/Res gestae. Ed. by E. Ackermann. 2017. Köln.

\section{Secondary sources}

Anderson, Parsons, Nisbet 1979: Anderson, R. D., Parsons, P. J., Nisbet, R.G.M. 1979. "Elegiacs by Gallus from Qasr Ibrim." The Journal of Roman Studies 69: 125-155.

Anonymus 1773: Anonymous. "Réfutation des conjectures de M. Poinsinet de Sivry sur la cause de l'exil d'Ovide." Journal Encyclopédique VII: 134-146.

Baccani 1992: Baccani, D. 1992. Oroscopi greci. Documentazione papirologica. Messina.

Bureth 1964: Bureth, P. 1964. Les titulatures impériales dans les papyrus, les ostraca et les inscriptions d'Égypte (30 a.C. -284 p. C.). Bruxelles.

Canfora 2006: Canfora, L. 2006. Giulio Cesare. Il dittatore democratico. Roma.

Carcopino 1964: Carcopino, J. 1964. "Les raisons religieuses de l'exil d'Ovide." Revue de l'Histoire des Religions 165: 132-139.

Cavafis 2013: Cavafis, C. 2013. Poesie. Ed. by F. M. Pontani. Milano.

Chwalek 1996: Chwalek, B. 1996. Die Verwandlung des Exils in die elegische Welt. Studien zu den Tristia und Epistulae ex Ponto Ovids. Frankfurt am Main.

Garlow 1936: Garlow, L. W. 1936. “A Guess as to Why Ovid Was Exiled.” The Classical Journal XXXII (2): 103-105.

Gold 2004: Gold, R. D. 2004. "Iovis Ira: Allusion and the Relegation of Ovid." In Daimonopylai Essays in Classics and the Classical Tradition presented to Edmund G, Berry. Ed. by R. B. Egan, M. Joyal, 127-142. Winnipeg.

Goodman 1997: Goodman, M. 1997. The Roman World 44 BC-AD 180. London-New York.

Hutchinson 2017: Hutchinson, G. O. 2017. "Some New and Old Light on Reasons for Ovid's Exile." Zeitschrift für Papyrologie und Epigraphik 203: 76-84.

Herklotz 2007: Herklotz, F. 2007. Prinzeps und Pharao. Der Kult des Augustus in Ägypten. Frankfurt am Main.

Horváth 1958: Horváth, I. K. 1958. "Impius Aeneas." Acta Antiqua Academiae Scientiarum Hungaricae VI: 385-393.

Ingleheart 2011: Ingleheart, J. 2011. A Commentary on Ovid. Tristia. Book 2. Oxford.

Jellonek 2017: Jellonek, Sz. 2017. "Capricorn and the star - the astrological symbols of Augustus." In Augustus. From Republic to Empire. Ed. by G. Bąkowska-Czerner and J. Bodzek, 74-82. Oxford.

Levick 1976: Levick, B. 1976. “The Fall of Julia the Younger.” Latomus 35: 301-339.

Levick 2010: Levick, B. 2010. Augustus. Image and Substance. Harlow.

Licandro 2008: Licandro, O. 2008. Aegyptum imperio populi Romani adieci: L'Egitto e la sua prefettura fra conservazione e innovazione nella politica Augustea. Napoli.

Lundström 1980: Lundström, S. 1980. Ovids Metamorphoseon und die Politik des Kaisers. Uppsala. 
Łukaszewicz 1984: Łukaszewicz, A. 1984. “Otoczenie Augusta i wielka własność ziemska w Egipcie." Meander 1: 23-31.

Łukaszewicz 2005: Łukaszewicz, A. 2005. Kleopatra. Ostatnia królowa starożytnego Egiptu. Warszawa.

Łukaszewicz 2006: Łukaszewicz, A. 2006. Egipt Greków i Rzymian. Warszawa.

Łukaszewicz 2007: Łukaszewicz, A. 2007. "Cezar w Egipcie.” In Grecy, Rzymianie i ich sasiedzi, Antiquitas XXIX. Ed by K. Nawotka et al., 443-452. Wrocław.

Łukaszewicz 2015: Łukaszewicz, A. 2015. "Fata mihi Caesar... Kilka uwag o Korneliuszu Gallusie.” In Charisteria Aliciae Szastyńska-Siemion octogenariae oblata ab amicis, collegis, discipulis. Ed. by G. Malinowski and M. Wróbel, 192-195. Wrocław.

Łukaszewicz 2016: Łukaszewicz, A. 2016. "Remarks on Mars Ultor, Octavian and Egypt.” In Mater familias. Scritti romanistici per Maria Zabłocka. JJP Supplement XXIX. Ed. by Z. Benincasa et al., 487-499. Varsavia.

Łukaszewicz 2016a: Łukaszewicz, A. 2016a. "Ptolemy XII and the Romans - an Alexandrian money story." The Polish Journal of Arts and Culture, New Series 3 (1): 29-39.

Łukaszewicz 2017: Łukaszewicz, A. 2017. "Octavian in Egypt. Propaganda and graffiti." In Augustus. From Republic to Empire. Ed. by G. Bąkowska-Czerner, J. Bodzek, 100-106. Oxford.

Łukaszewicz 2018: Łukaszewicz, A. 2018. "Głowa Pompejusza i inne ślady spotkania Rzymian z Egiptem." In Wybitni Rzymianie u schytku Republiki. Gnejusz Pompejusz Wielki (106-48 p. Chr.). Ed. by N. Rogosz, 183-189. Katowice.

Mac Keown 1984: Mac Keown, J. C. 1984. "Fabula proposito nulla tegenda meo." In Poetry and Politics in the Age of Augustus. Ed. by A. J. Woodman and D. West, 169-187. Cambridge.

Maleuvre 1995: Maleuvre, J.-Y. 1995. "Les Odes romaines d'Horace, ou un chef d'oeuvre ignoré de la cacozélie (presque) invisible." Revue belge de Philologie et d'histoire 73: 53-72.

Oxford Classical Dictionary, 1970. Ed. by N. G. L. Hammond, H. H. Scullard. Oxford.

Sauneron 1959: Sauneron, S. 1959. "Maat." In Dictionnaire de la civilisation égyptienne. Ed. By G. Posener et al., 156. Paris.

Sauneron 1959a: Sauneron, S. 1959. "Nout.” In Dictionnaire de la civilisation égyptienne. Ed. By G. Posener et al., 192. Paris.

Schoemann 1882: Schoemann, G. 1882. "Eine Muthmassung über den wahren Grund von Ovids Relegation.” Philologus XLI: 171-175.

Syme 1978: Syme, R. 1978. History in Ovid. London.

Śnieżewski 1993: Śnieżewski, S. A. 1993. Problem boskości Oktawiana Augusta w poezji augustowskiej. Kraków.

Terio 2006: Terio, S. 2006. Der Steinbock als Herrschaftszeichen des Augustus. "Orbis Antiquus" Bd 41. Ed. by Horst-Dieter Blume. Münster.

Thibault 1964: Thibault, J. C. 1964. The mystery of Ovid's exile. Berkeley.

Wallace-Hadrill 1987: Wallace-Hadrill, A. 1987. "Time for Augustus: Ovid, Augustus and the Fasti." In Homo Viator: Classical Essays for John Bramble. Ed. by M. Whitby et al., 221-230. Bristol.

Watson 1995: Watson, P. A. 1995. Ancient Stepmothers: Myth, Misogyny and Reality. Leiden.

Yoyotte 1959: Yoyotte, J. 1959. "Hathor." In Dictionnaire de la civilisation égyptienne. Ed. By G. Posener et al., 127. Paris.

Ziolkowski 2005: Ziolkowski, Th. 2005. Ovid and the Moderns. Ithaca and London. 


\section{DE OVIDIO ET AUREA AETATE AUGUSTI}

\section{Sum marium}

Pertractantur fata Publii Ovidii Nasonis poetae exquisitissimi qui Imp. Caesaris Augusti Divi filii tempore vixit et in nonnullis carminibus suis - sicut multi alii poetae - principem tamquam deum adorabat ac virtutes eius extollebat, sed ab irato Augusto repente in exsilium missus fuit, quo post seriem annorum e vita cessit. Quamvis se valde peccavisse ipse dicebat et ex Ponto ad Augustum de errore quodam et de carmine stulto scribebat, nihil tamen de istius peccati natura narravit. Princeps tamen Nasonis preces non exaudivit. Tiberius etiam, Augusti successor, Nasonem a Tomi Romam non revocavit.

Disputabatur postea cur relegatus fuisset. Non erat enim iudicatus neque Senatus exsilium eius decrevit, sed principis iussu ad fines imperii Romani fuit missus. Contra opinionem eorum qui audacem et quasi obscenam Artem Amatoriam demonstrant, existimat auctor Metamorphoseon libros in causa fuisse, et praecipue locum quo ferream aetatem Naso descripsit et universam morum pravitatem enarravit. Inter alia de novercis mentione facta qui venena praeparant, Liviam Augusti sine dubio irritavit de cuius veneficio fama vulgo ferebat. Augustus talem poetae audaciam tolerare non potuit et Nasonem relegavit sed veram exsilii causam publice declarare non est ausus, de qua causa et ipse Naso metu principis acriter indignati tacebat. 